\title{
$\begin{array}{llll}\mathbf{N} & \mathbf{O} & \mathbf{T} & \mathbf{E}\end{array}$
}

\section{Effect of Humidity to the Variation of Radon Daughter Concentration in a Building}

\author{
Hiroshi KoJImA ${ }^{* * 1}$ and Shiro ABE**,*2 \\ (Received August 20, 1984) \\ (Accepted June 5, 1985)
}

KEY WORDS: humidity effect, measurement, radon daughter, indoor reactor room, multiple regression

\section{INTRODUCTION}

In order to assess the dose due to the natural airborne radioactive nuclides, we have to know the level and variation of their concentrations in the air. People normally spend most of their time inside a building. Therefore, it is important to evaluate the concentration level and other additional data required for the dose evaluation of natural radionuclides in the indoor space. However, there are a few data available for the indoor air.

The concentration of radioactivity in the indoor air is based on a balance between source and sink; the source term includes the exhalation from the inner surface of the building and release from any other sources in the building. The sink term is mainly due to natural and forced ventilations together with radioactive decay. It is known that the character of these two terms is depended on various environmental factors. For instance, exhalation rate from the building materials is influenced by the change of atmospheric pressure. The dependency has been shown through model experiments ${ }^{1)}$ and through the in situ measurements

* 览島 紘, **阿部史朗

*1 Faculty of Science and Technology, Science University of Tokyo; Nodashi, Chiba-ken. 東京理科大学理工学部; 野田市山崎東龟山 (

*2 Division of Environmental Health, National Institu te of Radiological Science ; 1-9-4, Anagawa, Chiba-shi, Chiba-ken. 放射線医学総合研究所環境衛生研究部; 千葉市穴川 49-1 ( ( 260$)$

*3 KUR エアロゾル調查研究グループ（京大炉, 京大原研, 放医研, 名大工, 東海大工, 東理大理工) in the unventilated room. ${ }^{2,3)}$ Moreover, it is said that the natural ventilation rate of a building is affected by the wind velocity, wind direction and the temperature difference between the indoor and outdoor airs. These meteorological parameters have been found to be main contributors to the variation of radioactivity level of the indoor air. ${ }^{4,5)}$ It is usually considered that the other meteorological parameters affect the level of airborne nuclides indoors insignificantly.

Our research group ${ }^{* 3}$ has investigated the behavior of radon and radon daughters in a special building, reactor room. In the course of investigation, we obtained an interesting result about the influencing factors of radon daughter level. In this paper, we will discuss the result.

\section{MEASUREMENTS}

In order to make clear the behavior of radon and its daughters in indoor air, aerosol particles and some environmental factors together with radon daughters were measured in the reactor room of Research Reactor of Kyoto University (KUR). The reactor room with painted concrete walls was a cylindrical building of about $30 \mathrm{~m}$ in diameter whose volume was about $1.2 \times 10^{4} \mathrm{~m}^{3}$. In the reactor, the forced ventilation system with the exchange rate of about $3 \mathrm{hr}^{-1}$ was installed. Even under unventilated condition, the natural ventilation was not perfectly ignored; however, the ventilation rate through ducts and the others is fairly low. The measurements were performed during operation of the reactor, but these data were not used here.

To obtain the concentration data of radon 
daughters, we adopted a filter method in which the daughters were collected on a filter (Toyo Roshi, HE40T) through the suction of sample air and $\beta(\gamma)$ radiation from the collected daughters were counted by the use of a G.M. Tube Counter. In this method, the measured values of radioactivity will include contribution due to thoron daughters together with radon daughters. However, from the other measurements, it is known that contribution of thoron daughters to the gross counts is ignored. ${ }^{6)}$

On the aerosols, the concentrations of two size ranges of Aitken and Mie particles were measured by Pollak Counter and an optical counter with light scattering system, respectively. The Aitken particle corresponds to aerosol smaller than about
$10^{-5} \mathrm{~cm}$ in radius; Mie particle, larger than about $1.5 \times 10^{-5} \mathrm{~cm}$ in radius. Also, the mean radius of Aitken particles was obtained by combined use of the Pollak Counter and a diffusion battery.

Five series of measurements were carried out from 1978 to 1981 and in this report data of two series among them were used.

\section{ANALYTICAL RESULTS}

In order to estimate main influencing factors on the variation of radon daughter concentration, we adopted a means of multiple regression analysis. The relation used in this analysis was of the following equation,

$$
y=b_{0}+b_{1} X_{1}+b_{2} X_{2}+\cdots+b_{p} X_{p}
$$

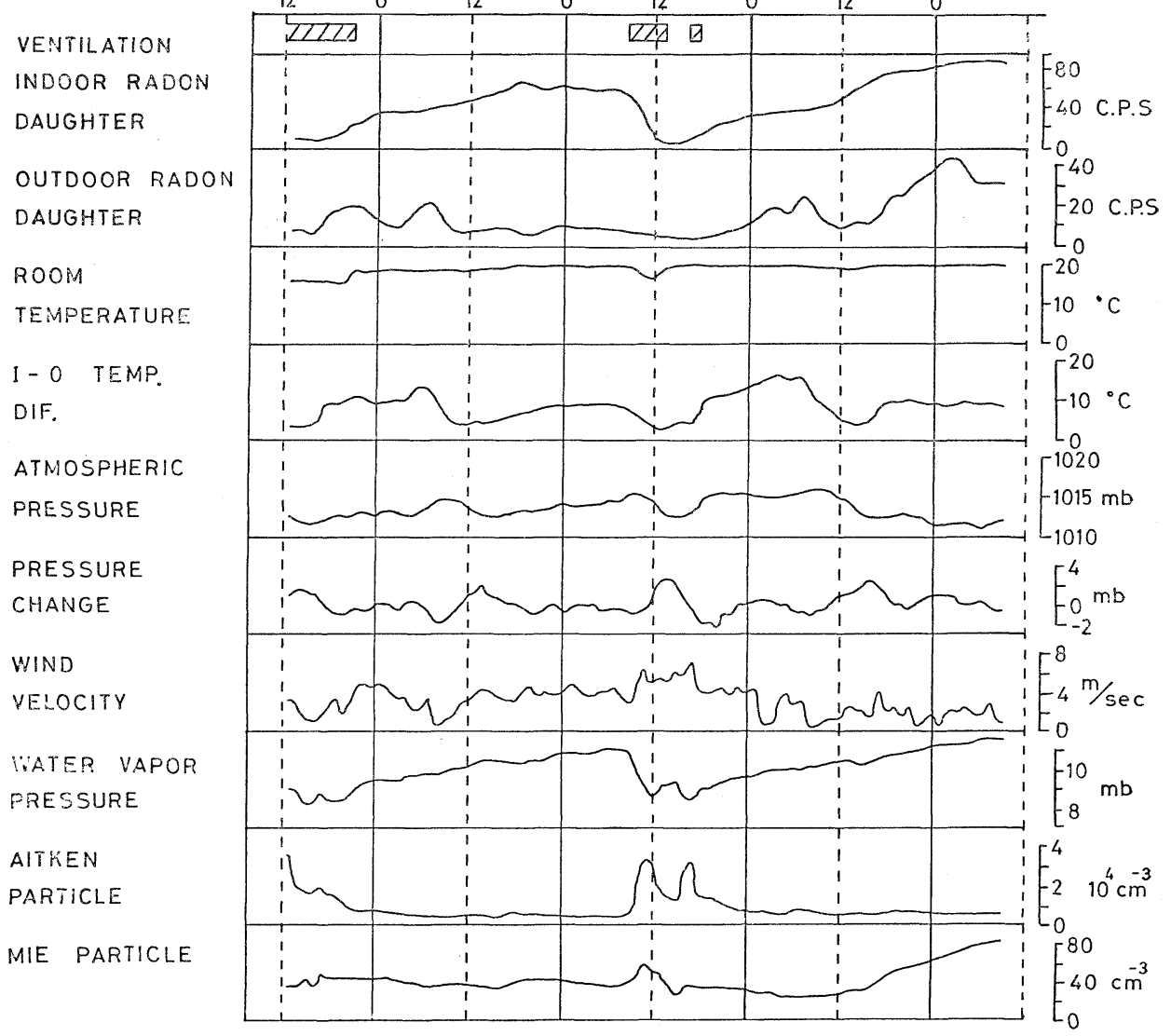

Fig. 1 An example of time variation of indoor radon daughter concentration and some environmental parameters, together with ventilation condition. In the ventilation condition, hatched parts indicate operated period of forced ventilation system. 
NOV, 1978

JAN. 1981

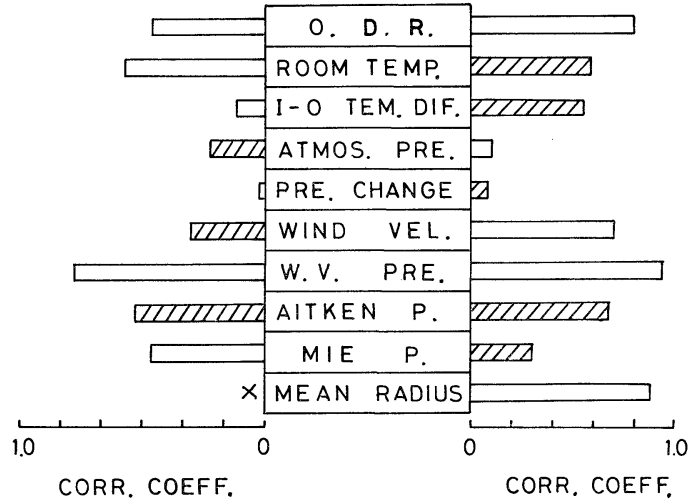

Fig. 2 Single correlation coefficients between indoor radon daughter concentration and independent variables. Hatched lines represent negative values.

where $y$ was called the dependent variable and $X_{p}$, the independent variables. Least square methods were used to estimate the partial regression coefficients, $b_{p}$ in the linear equation.

In the analysis, we selected the concentration of radon daughters in the room as dependent variable; the following environmental parameters were selected as independent variables. Those were atmospheric pressure, change of pressure $(3 \mathrm{hr}$ interval), room temperature, room water vapor pressure, temperature difference between indoor and outdoor airs (I-O Temp. Diff.), wind velocity, radon daughter concentrations in outdoor air (O.D.R.), number concentrations of Aitken and
Mie particles and mean radius of Aitken particles.

In Fig. 1, we show an example of time variation of dependent and independent variables together with the condition of ventilation. From the figure, we can easily see that the relation between the dependent variable and some independent variables is regarded as significant.

In Fig. 2, we show single correlation coefficients between indoor radon daughter concentration and independent variables; the hatched lines represent negative values. As is expected from Fig. 1, the relation between the radon daughter concentration and several factors seems to be significant. Among them, water vapor pressure has the highest correlation coefficient in both series of measurements. The next high values are those of room temperature and Aitken particle in the measurement in 1978, and are mean radius and the concentration of outdoor radon daughter in 1981. On the other hand, the variables related to the ventilation and exhalation such as wind velocity and pressure change give no good correlation.

Some variables like Aitken particle and mean radius may give apparently good correlation with the radon daughter in a high air tightness space. In general, the concentration of radon daughter increases due to build-up in the air tightness space, while the concentration of Aitken particle gradually decreases due to the mutual thermal coagulation and deposition to surrounding walls. The coagulation process results in the increase of radius of Aitken particle. This effect may provide the change of radon daughter concentration accom-

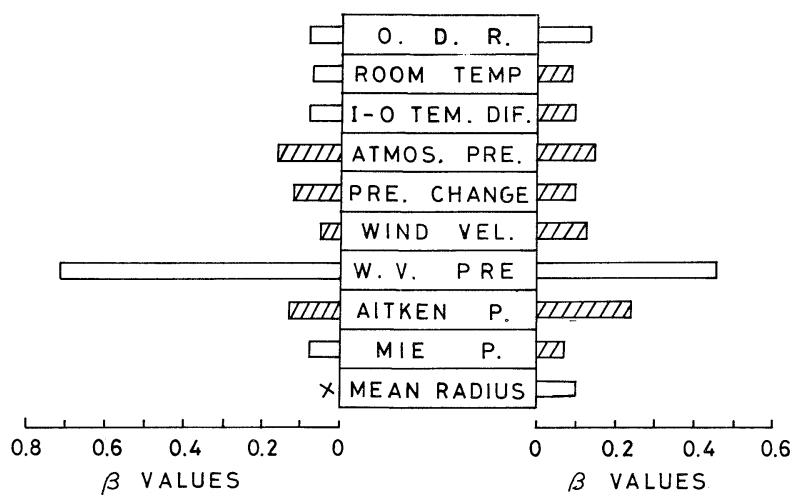

Fig. 3 Normalized partial regression coefficients ( $\beta$ values) for each independent variable. Hatched lines represent negative values. 
panied by a change in the concentration of aerosol particles.

In Fig. 3, we show the results of calculation of multiple regression analysis; the values in the figure are the normalized partial regression coefficients (represented by $\beta$ values) which are a measure of the extent of contribution of each independent variable to dependent variable. From measurements of two series, we can see that the common main influencing factor is water vapor pressure and the values are much larger than those of the other variables. The next influencing factors are the concentration of Aitken particle and atmospheric pressure in 1978 and those of Aitken particle and outdoor radon daughter in 1981. In analogy with the results of single correlation, there is relatively small contribution of parameters related to ventilation and exhalation.

In a building under high air tightness condition, it is expected that the most efficient parameters to change of radon daughter concentration are ones related to the exhalation of radon from surrounding walls. In the present measurements, it seems evident, from Fig. 3, that the $\beta$ values for water vapor pressure exceed those of the atmospheric pressure and atmospheric pressure change, related to the exhalation. As is stated before, relatively large contribution of aerosol particles may be due to a general tendency in a closed space; aerosol particles inadvertently resemble radon daughters in tendency of the concentration variation. But it should be emphasized that the $\beta$ values for water vapor pressure are much larger than those for Aitken particles.

Also, we calculated partial regression coefficients using relative humidity instead of water vapor pressure. The results showed the same tendency as those in Fig. 3.

\section{DISCUSSIONS AND CONCLUSIONS}

Most researchers have reported that the effect of humidity on the concentration of radon or radon daughters can normally be ignored. There is the only one study on the humidity effect as far as we know. ${ }^{7)}$ They experimentally examined the effect of humidity on the concentration of radon daughters. The humidity in the room was artificially changed and the other factors were kept constant; the radon daughters were detected by an apparatus based on a filter method. From the experiments, it was found that correlation between both changes of radon daughter concentration and water vapor pressure was significant.

It may be possible to explain the effect of humidity in two ways. One is caused by the measuring method of radon daughters. It is well-known that some kinds of apparatus for radon concentration are undesirably influenced by the change of humidity. ${ }^{8)}$ In the measuring apparatus which have detection system of free atoms, particularly charged atoms, the humidity gives a pronounced effect. However, in the present apparatus, which mainly collects radon daughters on aerosol particles, the effect can be ignored. On the other hand, the relative humidity may has an influence on size distribution of aerosol particles. The deformed size distribution may lead to the apparent change of concentration of radon daughters through the change of collection efficiency of the filter paper. In two size ranges of aerosol particles which we measured, however, the contribution of these concentrations and mean radius of Aitken particle to daughter concentration is much smaller than that of water vapor pressure of indirect factor. In this way, we can not conclude that the effect of humidity on the concentration of radon daughters is due to the measuring method.

The other may be caused by the emanation of radon. The exhalation of radon from building materials is not influenced by hunidity, but it is known that the moisture in the materials is related to an emanation factor which determine the transfer rate of radon from rock particles to air-filled pore in the materials. $\left.{ }^{9}, 10\right) \quad$ The enhanced moisture may increase the radon concentration in the air exhalated from these materials. However, there are few data indicating relation between the moisture in the materials and water vapor pressure in the room air. Therefore, we can not give conclusive explanation on the humidity effect.

The most remarkable result in the present study was that the predominant influencing factor to the variation of radon daughter concentration was water vapor pressure (or relative humidity). The result may only be expected to be valid under the specific condition of a high air tightness building which consists of concrete.

\section{REFERENCES}

1) J.P. McLaughlin and N. Jonassen; The effect of pressure drops on radon exhalation from walls, "Natural Radiation Environment III", ed. by T.F. 
GESELl and W.M. LOWDER, p. 1225 (1980).

2) J.P. Pohl-Ruling and E. Pohl; The radon-222 concentration in the atmospheres of mines as a function of the barometric pressure, Health Phys., 16, 579 (1969).

3) N. JoNASSEN; On the effect of atmospheric pressure variations on the radon-222 concentration in unventilated room, Health Phys., 29, 220 (1975).

4) F. Steinhausler; Long-term measurements of ${ }^{222} \mathrm{Rn},{ }^{220} \mathrm{Rn},{ }^{214} \mathrm{~Pb}$ and ${ }^{212} \mathrm{~Pb}$ concentration in the air of private and public buildings and their dependence on meteorological parameters, Health Phys., 29, 705 (1975).

5) E. Stranden and L. Berteib; Radon in dwellings and influencing factors, Health Phys., 39, 275 (1980).

6) M. SнIмо and T. КАтон; Radioactivity of radon and its short-lived decay products in room air(II)Transient state of radioactivities after start and/or stop of ventilation equipment, Hoken Butsuri, 18, 133 (1983) (in Japanese).

7) M. Money and B. Heaton; The effect of humidity on the detection on radon, Health Phys., 31, 457 (1976).

8) J. Porstendörfer, A. Wicke and A. Schraub; Methods for a continuous registration of radon, thoron and their decay products indoor and outdoors, "Natural Radiation Environment III," ed. by T.F. Gesell and W.M. Lowder, p. 1293 (1980).

9) A.B. TANNER; Radon migration in the ground: a supplementary review, "Natural Radiation Environment III," ed. by T.F. GESELL and W.M. LOWDER (1980).

10) K.P. Strong and D.M. Levins; Effect of moisture content on radon emanation from uranium ore and tailings, Health Phys., 42, 27 (1982). 